\title{
Bioerosion and sediment ingestion by the Caribbean parrotfish Scarus vetula and Sparisoma viride: implications of fish size, feeding mode and habitat use
}

\author{
J. H. Bruggemann*, A. M. van Kessel, J. M. van Rooij, A. M. Breeman \\ Dept of Marine Biology, University of Groningen, PO Box 14, 9750 AA Haren, The Netherlands
}

\begin{abstract}
Erosion rates and sources of sediment ingested were quantified for the 2 most abundant parrotfish species on a leeward fringing reef of Bonaire. Netherlands Antilles: Scarus vetula and Sparisoma viride. Direct estimates of erosion by different size classes were obtained from daily feeding rates and grazing scar frequency, scar volume and substrate density. Foraging preference and distribution of fish on the reef were used to examine patterns of bioerosion at 2 spatial scales: reef zones and individual substrates used for grazing. Sediment mass ingested by fish provided an independent check on erosion rates, and was partitioned according to source. S. vetula, employing a scraping feeding mode, removed less material from grazed substrates than similar sized $S$. viride, which forages by excavating the substrate. Erosion rates increased strongly with fish size in both species. The (indigestible) carbonate derived from epilithic algae accounted for all sediment ingested by juvenile fish. In adult fish, the proportion of freshly eroded carbonate substrate ingested increased with fish size. The distribution of adults of these large scarids over different reef zones determines the rate of bioerosion on a large spatial scale. The highest bioerosional rates occur on the shallow reef (ca $7 \mathrm{~kg} \mathrm{~m}^{-2} \mathrm{yr}^{-1}$ ), and they decrease with depth. Parrotfish foraging preferences, and the effects of food type and skeletal density of substrates on the size of the grazing scars, cause large differences in bioerosional rates on a small spatial scale. The highest rates of bioerosion occur on substrates infested with boring algae and of low skeletal density, while high-density substrates and substrates covered with crustose corallines undergo lower rates. Living coral is rarely eaten by scarids, and largely escapes erosion by grazing.
\end{abstract}

KEY WORDS: Coral reefs - Bioerosion rates - Scaridae Skeletal density - Food type Population density $\cdot$ Spatial variability

\section{INTRODUCTION}

Both ancient and modern coral reefs are shaped by the interaction between reef growth and reef destruction. Growth of the reef framework is dominated by biological agents, among which living corals and crustose coralline algae constitute the major carbonate producers (Stearn et al. 1977. Hubbard \& Scaturo 1985). In the destruction of reef substrates, biological agents such as grazers (e.g. herbivorous fishes and sea urchins) and endolithic borers (e.g. boring algae, polychaetes, sipunculans and sponges) can also play a dominant role. Previous studies (Scoffin et al. 1980,

·E-mail: j.h.bruggemann@biol.rug.nl
Davies 1983, Bak 1990, Hubbard et al. 1990) indicated that variation in bioerosion rates are as important as the variations in $\mathrm{CaCO}_{3}$ production in forming the physical and biological features of a reef. The relative importance of endolithic borers and grazers for the destruction of reef substrates varies between reef environments (Davies \& Hutchings 1983, Kiene \& Hutchings 1994b) and with time of exposure (Hudson 1977. Kiene \& Hutchings 1994a). Quantitative studies indicated, however, that in most reef habitats bioerosion of substrates is predominantly caused by grazing (Kiene 1985, Hutchings 1986, Bak 1990, 1994).

Parrotfish (Scaridae) are a major component of the herbivorous fish community on coral reefs (Russ 1984a, b. Lewis 1986). Most scarid species feed by scraping off 
algae that grow on and in dead coral skeletons. Along with their food, they often remove large quantities of substrate (Randall 1967, Horn 1989, Bellwood \& Choat 1990). Old sediment trapped in epilithic algal turfs is another important source of sediment ingested by these fish. Feeding mode differs among scarid species (Frydl \& Stearn 1978, Bellwood \& Choat 1990, Bruggemann et al. 1994C), and determines the extent to which the reef surface is excavated. Moreover, the relative importance of epilithic algal turfs and substrate-bound algal fractions (crustose corallines and endolithic algae) exploited as food resources changes during ontogeny (Bruggemann et al. 1994a, b, c). Therefore, both the total amount of sediment produced and the composition of the sediment ingested will vary according to fish size and species-specific differences in feeding mode.

Previous studies that aimed to quantify parrotfish bioerosion on Caribbean reefs (Gygi 1975, Ogden 1977. Frydl \& Stearn 1978) have usually employed indirect methods, measuring total sediment ingestion and estimating the proportion of reworked sediment. This study aims to provide more realistic estimates of scarid bioerosion by using direct methods to quantify carbonate removal from grazing scars in combination with field observations of fish foraging behaviour and their distribution on the reef.

For 2 common Caribbean scarids, Scarus vetula (Bloch \& Schneider) and Sparisoma viride (Bonnaterre), habitat use and feeding behaviour were studied in a larger project, aiming to evaluate the role of parrotfish in the trophodynamics of coral reefs (Bruggemann et al. 1994a, b, c). The present study evaluates the role of $S$. vetula and $S$. viride in the erosion of reef substrates. Special effort was made to quantify the effects of fish size and feeding mode on erosion rates. Field observations on foraging and habitat preference were used to quantify bioerosion at 2 spatial scales: reef zones and substrate types used for grazing. Quantification of sediment mass ingested by fish provided an independent check on erosion rates calculated using direct methods, and enabled an evaluation of their sources.

\section{MATERIALS AND METHODS}

Study site and parrotfish abundance. The study was performed between February 1989 and January 1992 at Karpata $\left(12^{\circ} 13^{\prime} \mathrm{N}, 68^{\circ} 20^{\prime} \mathrm{W}\right)$, which is part of a continuous fringing reef on the leeward southwest coast of Bonaire, Netherlands Antilles. Field observations were carried out using SCUBA with notes taken on PVC slates, while laboratory experiments were performed at the nearby field station. A detailed description of the reef at the study area is provided by Bruggemann et al. (1994a). The reef profile comprises:

- a $30 \mathrm{~m}$ wide shallow reef zone ( 0.3 to $3.5 \mathrm{~m}$ depth), dominated by coarse rubble from dead Acropora palmata colonies, with scattered live coral colonies of the same species.

- a $26 \mathrm{~m}$ wide gorgonian zone ( 3.5 to $6 \mathrm{~m}$ depth), of which the bottom is formed by a fossil carbonate platform, largely covered with sediment and rubble of Acropora cervicornis.

- a $17 \mathrm{~m}$ wide drop-off zone ( 6 to $12 \mathrm{~m}$ depth), dominated by massive heads of Montastrea annularis.

- a $15 \mathrm{~m}$ wide upper reef slope (12 to $25 \mathrm{~m}$ depth), where coral cover is dominated by colonies of $M$. annularis and Agaricia agaricites.

Parrotfish density (ind. ha ${ }^{-1}$ ) and size distribution were determined by repeated visual surveys in a permanent transect covering the main reef zones. Perpendicular to the coast, a $15 \mathrm{~m}$ wide transect of adjacent permanent quadrats was roped off, ranging from 0.3 to $22 \mathrm{~m}$ depth. The nearshore part of the reef, which consists mainly of a $4 \mathrm{~m}$ wide reef crest ( 0 to $0.3 \mathrm{~m}$ depth) formed by dead but erect Acropora palmata coral, was not surveyed regularly. Under prevailing weather conditions the surge makes this uppermost part of the reef inaccessible. The transect was divided into 5 adjacent quadrats, measuring either $10 \times 15 \mathrm{~m}$ or $15 \times 15 \mathrm{~m}$, all of which were subdivided into $5 \times 5 \mathrm{~m}$ squares. First, an entire quadrat was examined at a distance of ca $3 \mathrm{~m}$ to record species and life phase (initial phase and terminal phase) of individual adult fish, after which they were assigned to a $5 \mathrm{~cm}$ size class based on estimated fork length ( $F L$, measured from the tip of the upper jaw to the end of the middle caudal rays). Adult scarids were defined as individuals large enough to engage in sexual activity, as inferred from field observations. The 3 smaller species (i.e. Scarus taeniopteris, Scarus iserti and Sparisoma aurofrenatum) reach that state at $\mathrm{FL} \geq$ $10 \mathrm{~cm}$, while the other, larger species are adult at $\mathrm{FL} \geq$ $1.5 \mathrm{~cm}$. Subsequently, the $5 \times 5 \mathrm{~m}$ squares were searched at close range for the presence of juvenile fish, which were identified to species level when possible, and allocated to a $5 \mathrm{~cm}$ size class, except for the smallest individuals that were divided into a $0-2$ and a $2-5 \mathrm{~cm}$ size class. At 7 time intervals a total of $28 \mathrm{cen}-$ suses was performed by 2 independent observers (J.H.B. and J.M.v.R.). For each reef zone, the mean $( \pm$ SE) of all surveys was used to calculate the average density (ind $\mathrm{ha}^{-1}$ ) and size distribution of scarids. Average density over the entire reef profile was calculated by weighting the means per reef zone with the width of each zone. Estimated FL was converted to fish body mass (BM) using species-specific length-mass relationships which were determined for fish caught in the study area as described by Bruggemann et al. (1994d). 
Foraging behaviour of Scarus vetula and Sparisoma viride. A comparative analysis of foraging behaviour of Scarus vetula and Sparisoma viride (Bruggemann et al. $1994 \mathrm{c}$ ) indicated that $S$. vetula employs a scraping feeding mode (sensu Bellwood \& Choat 1990). In contrast, $S$. viride forages by excavating the substrates. Direct observations were made by following individual fish (of noted size and species) until the exact location of a bite could be seen. The proportion of bites that leave a grazing scar on the substrate was thus determined. Bites were selected randomly, and the size of grazing scars was measured as described by Bruggemann et al. $(1994 \mathrm{a}, \mathrm{c})$. Regression of log-transformed data showed that the surface area $\left(S A, \mathrm{~cm}^{2}\right)$ of grazing scars is linearly related to $\mathrm{FL}^{2}$; grazing scar volume $\left(V O, \mathrm{~cm}^{3}\right)$ is linearly related to $\mathrm{FL}^{3}$. Averaged for all observations these linear relationships are:

Scarus vetula:

$$
\begin{gathered}
S A=4.013(\mathrm{SE}: 0.241) \times 10^{-4} \times \mathrm{FL}^{2} ; \\
\mathrm{r}^{2}=0.675 ; \mathrm{n}=136 \\
V O=0.193(\mathrm{SE}: 0.020) \times 10^{-6} \times \mathrm{FL}^{3} ; \\
\mathrm{r}^{2}=0.418 ; \mathrm{n}=133
\end{gathered}
$$

Sparisoma viride:

$$
\begin{gathered}
S A=5.257(\mathrm{SE}: 0.174) \times 10^{-4} \times \mathrm{FL}^{2} \\
\mathrm{r}^{2}=0.731 ; \mathrm{n}=414 \\
V O=1.295(\mathrm{SE}: 0.066) \times 10^{-6} \times \mathrm{FL}^{3} ; \\
\mathrm{r}^{2}=0.524 ; \mathrm{n}=393 .
\end{gathered}
$$

Food type and substrate skeletal density had no effect on the size of grazing scars left by S. vetula (Bruggemann et al. 1994c), but both factors significantly affected the size of scars made by $S$. viride (Bruggemann et al. 1994a). The effect of substrate density on the size of excavations made by $S$. viride was further investigated by determining the slope of the linear regression of $V O$ to $\mathrm{FL}^{3}$ for each type of dead coral substrate.

Selection of food and substrate types by Scarus vetula as dependent on life-phase and foraging depth has been described by Bruggemann et al. (1994c). Mean daily feeding rates (bites $\mathrm{d}^{-1}$ ) as dependent on life phase and body size were also quantified in this study. For Sparisoma viride, foraging selectivity and mean daily feeding rates were described by Bruggemann et al. (1994a, b).

Mass of carbonate removed from grazing scars. For each scar, the mass of carbonate removed was calculated from grazing scar $V O$ (see above) and the density of the grazed substrate. Skeletal density $\left(\mathrm{g} \mathrm{cm}^{-3}\right)$ was determined from replicate ( $\mathrm{n}=3$ to 7 ) sample blocks that were cut with a diamond gem-saw from known coral species (living and dead). Dry mass (DM) of blocks was determined to the nearest mg, while volume was determined to the nearest $\mathrm{ml}$ by water displacement, after coral pores had been sealed off with petroleum jelly. To determine the skeletal density of the surface layer of the dead coral substrates that were inhabited by boring algae, SEM photographs $(\mathrm{n}=6$, $200 \times$ magnification, Canscan model S4 electron microscope with Robinson detector for back-scattering electrons) were taken from polished $(0.1 \mu \mathrm{m}$ grain size) cross-sections of resin embedded dead coral substrates (Acropora cervicornis and A. palmata) that were first treated with domestic bleach to remove organic matter. Image analysis (OPTIMAS program) showed that in the upper $0.3 \mathrm{~mm}$ of substrates an average of $21 \%$ of the calcium carbonate was removed by boring algae and fungi. The density of dead coral substrates inhabited by boring algae was estimated by correcting coral skeletal density with the percentage of material removed. The skeletal density of crustose coralline algae $\left(1.56 \mathrm{~g} \mathrm{~cm}^{-3}\right)$ was taken from Stearn et al. (1977). Analysis of covariance (ANCOVA; Norusis 1990), with skeletal density and food type as main effects and $\mathrm{FL}^{3}$ as covariate, was used to investigate factors affecting the mass of carbonate removed from grazing scars.

Erosion rates. To calculate mean carbonate mass ${ }_{ \pm}$SE removed from grazing scars for each size class of Scarus vetula and Sparisoma viride, linear regressions of carbonate mass removed to $\mathrm{FL}^{3}$ were used. In $S$. viride, food type significantly affected the mass of carbonate removed. Therefore, in quantifying erosion rates by $S$ viride, food preference was taken into account, and for each food type, the appropriate relationship between fish size and mass of carbonate removed per grazing scar was used.

For different size classes, erosion rates were calculated as follows. Erosion rate per bite $\left(g b^{b i t e^{-1}}\right)=$ mass of carbonate removed from grazing scars $\times$ the proportion of bites that leave a scar. Erosion rate per day ( $g$ ind..$\left.^{-1} \mathrm{~d}^{-1}\right)=$ erosion rate per bite $x$ mean daily feeding rate. Annual erosion rates were calculated by multiplying daily rates by 365 . Overall error terms for each size class were calculated using Goodman's estimator (Travis 1982).

Mass and source of sediment ingested. Sediment mass ingested per bite was quantified and compared to the erosion rate per bite in order to (1) provide an independent check on the erosion rates calculated directly from grazing scars, and (2) enable partitioning of ingested sediment according to source.

Mass of ingested sediment in fish with empty and partly filled guts was determined by dissection of fish, and removing the gut with contents. Gut with contents was divided into 3 parts (duodenum, jejunum and rectum), and each part dried at $60^{\circ} \mathrm{C}$ to constant weight (DM). Gut sections were homogenized by grinding with pestle and mortar, after which the ash contents of each gut section was determined by weighing replicate subsamples ( $\mathrm{n}=2$ to 4 ) to the nearest $0.1 \mathrm{mg}$, and reweighing after ashing for $6 \mathrm{~h}$ at $500^{\circ} \mathrm{C}$ 
Fish with empty guts were obtained by keeping them overnight in a clean tank with running seawater They were also collected on the reef at dawn, before the onset of feeding. Upon dissection no part of the gut was visibly filled, except for the rectum which sometimes contained a faecal pellet consisting of food remains that were ingested the previous day. Fish with partly filled guts were collected in the morning before their first defecation (not counting the faecal pellet described above). For each fish, the number of bites taken since the onset of feeding was recorded, after which it was collected using a spear. The loss of intestinal contents through excretion of faeces or through injuries of the gut was prevented by spearing the fish in the head or back and killing it instantly. All fish were collected from the shallow reef and gorgonian zone during the final months of the study. Mass of ingested sediment in fish with partly filled guts was corrected for the mass of ash present in fish with empty guts. BM of fish with partly filled guts was corrected for the mass of ingested sediment so that corrected BM approximates that of fish with empty guts. The mass of sediment ingested per bite was calculated as:

Corrected mass of ingested sediment/No. of bites

Total sediment ingested per bite by fish foraging in the field was partitioned according to origin. Sediment sources are: (1) carbonate eroded from grazed substrates; (2) carbonate derived from epilithic algae; and (3) old sediment trapped in the algal turfs. For different size classes, the mass of substrate-derived carbonate (source 1) ingested per bite was assumed to be equal to the erosion rate per bite (see above). The mass of carbonate derived from epilithic algae (source 2) ingested per bite was estimated for each size class from the $S A$ of the grazing scars, the standing crop ( $\mathrm{mg} \mathrm{DM} \mathrm{cm}^{-2}$ ) and the ash fraction of epilithic algal turfs. To determine algal standing crop, dead coral substrates with associated algae from which trapped sediment was removed by rinsing in seawater were collected on the reef, trimmed with a diamond saw, after which the epilithic turfs were removed with a scalpel. Care was taken that no crustose corallines or endolithic algae were removed as well. The surface area of samples was determined by carefully modelling heavy-duty aluminium foil of known weight over the substrate, and weighing this after drying. DM of algal samples was determined to the nearest $0.1 \mathrm{mg}$, while their ash fraction was determined as described above. From the diet composition of fish grazing on the shallow reef and the gorgonian zone (Bruggemann et al. 1994a, c) it was estimated that the mass of carbonate from epilithic algal turfs grazed by Scarus vetula averaged $2.45 \mathrm{mg}$ $\mathrm{cm}^{-2}$, and $3.14 \mathrm{mg} \mathrm{cm}^{-2}$ for Sparisoma viride. Finally, mass of sediment from source 1 and 2 was subtracted from the total mass of sediment ingested per bite to estimate the proportion of old, reworked sediment trapped in the algal turfs (source 3 ).

Spatial patterns of bioerosion. Reef erosion rates $\left(\mathrm{kg} \mathrm{m}^{-2} \mathrm{yr}^{-1}\right)$ by Scarus vetula and Sparisoma viride populations in different reef zones were calculated as:

$$
\sum_{n=1}^{1} \bar{x}_{1} \hat{y}_{i} \cdot \bar{z}_{i}
$$

in which $\bar{X}_{1}$ is mean density $\times 10^{-4}, \hat{y}$, is predicted erosion rate per bite $\times 10^{-3}$, and $\bar{z}_{1}$ is mean daily feeding rate $\times 365$ of fish of size class $i$, for $n=1, \ldots, i$ size classes belonging to all life phases for both species. For each size class, error terms were calculated using an expanded 3-term version of Goodman's estimator following Bellwood (1995a):

$$
\begin{aligned}
& \mathrm{SE}^{2}(\bar{x} \dot{y} \bar{z})=(\bar{x} \cdot \hat{y})^{2} \cdot \mathrm{SE}^{2} z+(\bar{x} \cdot \bar{z})^{2} \cdot \mathrm{SE}^{2} y+(\hat{y} \cdot \bar{z})^{2} \cdot \mathrm{SE}^{2} \bar{x} \\
& +(\bar{x})^{2} \cdot \mathrm{SE}^{2} \dot{y} \cdot \mathrm{SE}^{2} \bar{z}+(\hat{y})^{2} \cdot \mathrm{SE}^{2} \bar{x} \cdot \mathrm{SE}^{2} \bar{z}+(\bar{z})^{2} \cdot \mathrm{SE}^{2} \bar{x} \cdot \mathrm{SE}^{2} \dot{y} \\
& +\mathrm{SE}^{2} \bar{x} \cdot \mathrm{SE}^{2} \dot{y} \cdot \mathrm{SE}_{\bar{z}}^{2}
\end{aligned}
$$

Overall error terms for parrotfish bioerosion in each reef zone were calculated by adding error terms of all size classes of $S$. vetula and $S$. viride.

For each reef zone, erosion rates of substrates containing different food types were determined. Three main food types were distinguished: (1) substrates inhabited by endolithic algae; (2) substrates covered by crustose coralline algae; and (3) living corals. The mass of carbonate removed from each food type was calculated from the annual erosion rates $x$ the proportion of bites taken on each food type, both variables varying according to species, life phase, size class and foraging depth. Food type-specific erosion rates $(\mathrm{kg}$ $\mathrm{m}^{-2} \mathrm{yr}^{-1}$ ) were calculated as the cumulative of the erosion rates of all size classes of the 2 species, divided by the surface area $\left(\mathrm{m}^{2} \mathrm{~m}^{-2}\right)$ of each food type. The relative abundance of food types in each reef zone was quantified using chain-link transects (Porter 1972) as described by Bruggemann et al. (1994a). For each transect, a surface index was determined by dividing the length of a survey chain by the linear distance it spanned. The surface area $\left(\mathrm{m}^{2} \mathrm{~m}^{-2}\right)$ accupied by different food types was determined by multiplying its relative abundance by the mean surface index (SI) of the reef section in which it is contained.

\section{RESULTS}

\section{Standing stock of parrotfish}

Scarus vetula and Sparisoma viride were the most abundant species in the study area. Due to their high abundance and relatively large body size, they repre- 
sented 52 and $31 \%$ respectively of the total scarid biomass (Table 1). The last column in Table 1 includes Sparisoma chrysopterum and Sparisoma rubripinne, which represented 0.6 and $1.0 \%$ of the total scarid biomass respectively. Other parrotfish, not included in Table 1, were sometimes observed in the study area. These are Scarus coerulus and Scarus coelestinus, together representing less than $0.5 \%$ of the total scarid biomass

Density of adult Scarus vetula and Sparisoma viride was highest on the shallow reef and decreased with depth (Fig. 1). Density of juvenile parrotfish was lowest on the shallow reef and reef slope, and highest at intermediate depths.

\section{Mass of carbonate removed from grazing scars}

In Scarus vetula, neither the skeletal density of grazed substrates nor food type affected the mass of carbonate removed from scars (ANCOVA, substrate density: $F_{(4,118)}=2.042, \mathrm{p}=0.093$; food type: $F_{(1,131)}=$ $1.828, p=0.179)$. Substrate types tested were dead coral substrates of Acropora cervicornis, A. palmata, Agaricia spp., Montastrea annularis and Madracis mirabilis; food types tested were: substrates inhabited by endolithic algae and those covered by crustose coralline algae. Hence, to quantify erosion rates by $S$. vetula, a single relationship between fish size and the mass of carbonate removed from each grazing scar was used: carbonate mass removed $\left(\mathrm{g} \mathrm{scar}^{-1}\right)=0.306(\mathrm{SE}$ : $0.092) \times 10^{-6} \times \mathrm{FL}^{3}$.

In Sparisoma viride, the fish size-specific volume of grazing scars was negatively correlated with the skeletal density of substrates (Fig. 2). This implies that $S$. viride will erode dead coral substrates of low density (e.g from Colpophyllia natans and Montastrea annularis) faster than those of high density (e.g. from Acropora palmata and A. cervicornis). However, skeletal density of substrates did not affect the mass of carbonate removed from grazing scars (ANCOVA, $\left.F_{(6,306)}=0.776, p=0.590\right)$. In contrast, food type did significantly affect carbonate mass removed from scars (ANCOVA, $F_{(2,375)}=3.234, p<0.05$ ). For each food type, the slope \pm SE of the linear regression of carbonate mass removed from scars to fish size is given in Fig 3.

\section{Erosion rates in relation to feeding mode, fish size, life phase and foraging depth}

Bites that leave a visible grazing scar increased in frequency with increasing fish size (Fig. 4). Adult Sparisoma viride ( $\geq 15 \mathrm{~cm}$ FL) produced grazing scars more frequently than did adult Scarus vetula. No such difference was found, however, between juveniles of these species

Table 1. Average density (ind. ha ${ }^{-1}$ ) \pm SE by size class, and average total biomass ( $\mathrm{kg} \mathrm{ha}^{-1}$ ) of parrotfish in a $15 \mathrm{~m}$ wide reef transect from 0.3 to $22 \mathrm{~m}$ depth. Species are ranked by decreasing density and biomass. Sparisoma spp. includes $S$. chrysopterum and S. rubripinne

\begin{tabular}{|c|c|c|c|c|c|c|c|}
\hline Life phase & $\begin{array}{l}\text { Size class } \\
(\mathrm{cm} \mathrm{FL)}\end{array}$ & $\begin{array}{l}\text { Scarus } \\
\text { vetula }\end{array}$ & $\begin{array}{l}\text { Sparisoma } \\
\text { viride }\end{array}$ & $\begin{array}{c}\text { Scarus } \\
\text { taeniopteris }\end{array}$ & $\begin{array}{c}\text { Scarus } \\
\text { iserti }\end{array}$ & $\begin{array}{l}\text { Sparisoma } \\
\text { aurofrenatum }\end{array}$ & $\begin{array}{c}\text { Sparisoma } \\
\text { spp. }\end{array}$ \\
\hline Juvenile & $\begin{array}{c}<2 \\
2-4 \\
5-9 \\
10-14\end{array}$ & $\begin{array}{l}53.9 \pm 15.8 \\
70.7 \pm 13.7 \\
70.3 \pm 13.3 \\
51.2 \pm 6.5\end{array}$ & $\begin{array}{l}38.0 \pm 9.0 \\
81.8 \pm 13.7 \\
57.2 \pm 11.6 \\
19.3 \pm 5.4\end{array}$ & $\begin{aligned} &- \\
& 1.1 \pm 1.1 \\
& 32.8 \pm 7.8 \\
&-\end{aligned}$ & $\begin{array}{c}6.5 \pm 5.3 \\
7.1 \pm 3.5 \\
27.9 \pm 10.1\end{array}$ & $\begin{aligned} 44.1 & \pm 9.9 \\
126.5 & \pm 21.0 \\
61.3 & \pm 10.3 \\
& -\end{aligned}$ & $\begin{array}{c}- \\
0.4 \pm 0.3 \\
5.5 \pm 2.2 \\
6.4 \pm 3.1\end{array}$ \\
\hline Initial phase & $\begin{array}{c}<15 \\
15-19 \\
20-24 \\
25-29 \\
\geq 30\end{array}$ & $\begin{array}{c}- \\
80.8 \pm 11.4 \\
114.6 \pm 12.6 \\
157.9 \pm 14.3 \\
80.7 \pm 8.3\end{array}$ & $\begin{array}{l}\quad- \\
23.4 \pm 6.0 \\
39.5 \pm 8.8 \\
72.0 \pm 10.1 \\
50.0 \pm 8.8\end{array}$ & $\begin{aligned} 63.3 & \pm 10.8 \\
137.8 & \pm 16.1 \\
35.1 & \pm 10.9 \\
0.3 & \pm 0.3\end{aligned}$ & $\begin{aligned} 77.8 & \pm 16.9 \\
99.0 & \pm 18.3 \\
16.0 & \pm 5.9 \\
0.7 & \pm 0.7 \\
& -\end{aligned}$ & $\begin{aligned} 42.9 & \pm 9.0 \\
29.4 & \pm 6.8 \\
4.5 & \pm 3.0 \\
& - \\
& -\end{aligned}$ & $\begin{array}{c}- \\
2.1 \pm 1.3 \\
3.1 \pm 2.0 \\
8.4 \pm 3.7 \\
3.0 \pm 1.6\end{array}$ \\
\hline Terminal phase & $\begin{array}{c}<15 \\
15-19 \\
20-24 \\
25-29 \\
30-34 \\
35-39 \\
\geq 40\end{array}$ & $\begin{array}{c}- \\
- \\
0.9 \pm 0.9 \\
6.8 \pm 2.9 \\
28.1 \pm 6.2 \\
59.2 \pm 7.6 \\
19.8 \pm 3.1\end{array}$ & $\begin{aligned} &- \\
& 4.0 \pm 2.3 \\
& 3.7 \pm 2.0 \\
& 19.8 \pm 5.5 \\
& 39.8 \pm 8.3 \\
& 38.5 \pm 8.5 \\
& 1.2 \pm 1.2\end{aligned}$ & $\begin{aligned} &- \\
& 13.6 \pm 5.4 \\
& 33.8 \pm 7.0 \\
& 17.6 \pm 5.7 \\
&- \\
&-- \\
&-\end{aligned}$ & $\begin{aligned} & - \\
10.2 & \pm 3.7 \\
22.6 & \pm 5.5 \\
5.4 & \pm 3.4 \\
& - \\
& - \\
& -\end{aligned}$ & $\begin{aligned} 2.0 & \pm 1.5 \\
14.1 & \pm 4.7 \\
12.7 & \pm 4.7 \\
0.9 & \pm 0.9 \\
& - \\
& - \\
& -\end{aligned}$ & $\begin{array}{c}- \\
- \\
0.7 \pm 0.7 \\
0.3 \pm 0.3 \\
0.3 \pm 0.3 \\
0.3 \pm 0.3 \\
0.7 \pm 0.7\end{array}$ \\
\hline Total biomass & & 270.8 & 1632 & 37.8 & 23.7 & 11.0 & 8.3 \\
\hline
\end{tabular}



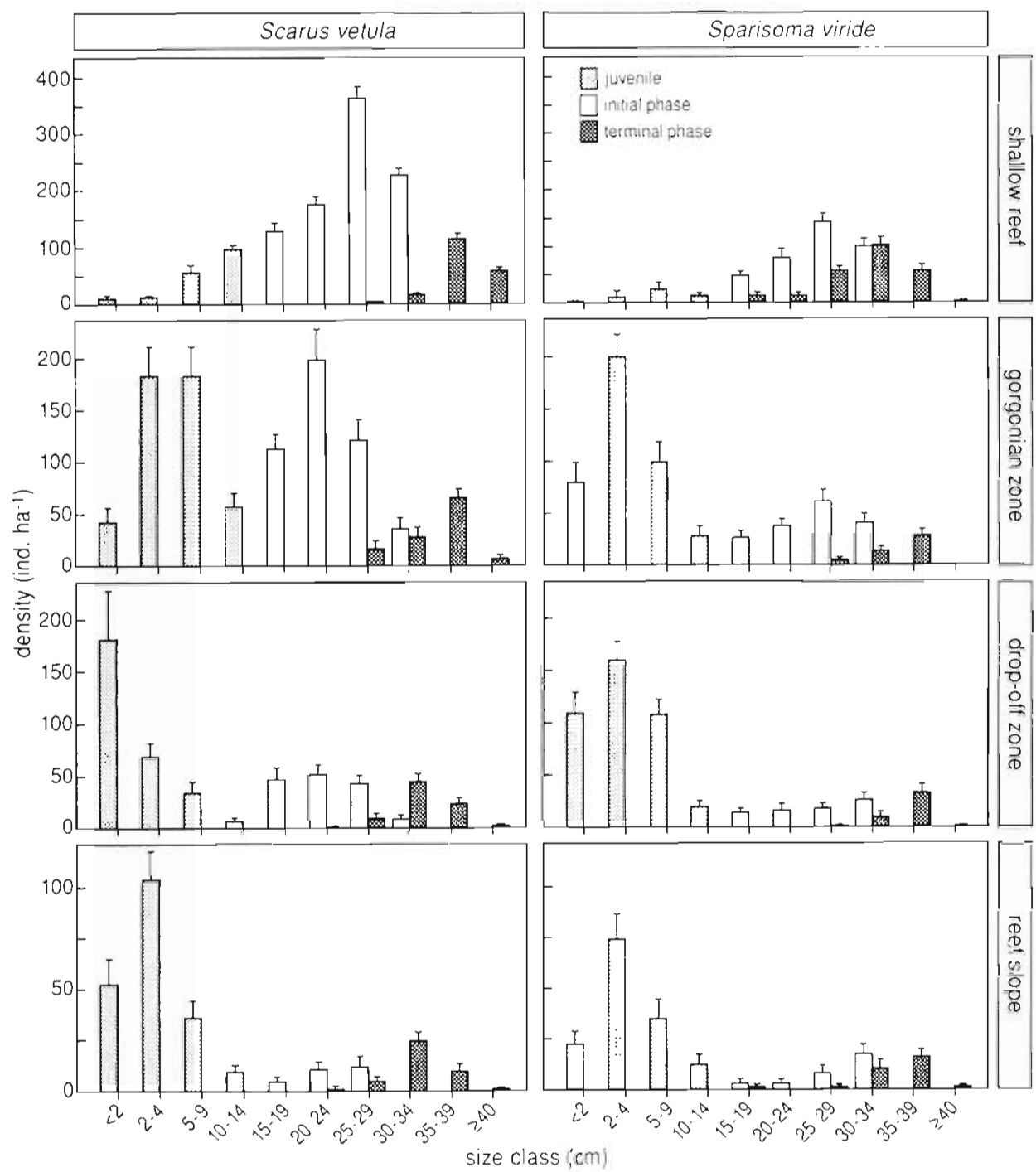

Fig. 1 Scarus vetula and Sparisoma viride. Average density (ind $\mathrm{ha}^{-1}$ ) by size class and life phase in different reef zones. Error bars indicate 1 SE. Note the difference in scale for different reef zones

The erosion rate per bite by Sparisoma viride is more than an order of magnitude higher than in Scarus vetula (Fig. 5). In spite of 2.5 to 4 times higher daily feeding rates of $S$. vetula (Table 2), the daily erosion rates by $S$. viride are 3 to 10 times higher than those by $S$. vetula of similar size (Fig. 5). For both species, erosion by juvenile fish is negligible. Daily erosion rates by initial phase fish of both species are higher than by terminal phase fish, resulting from higher daily feeding rates. $S$. viride that live inside territories on the deeper reef ( $\geq 3.5 \mathrm{~m}$ depth) exert lower feeding rates that non-territorial conspecifics on the shallow reef (Table 2). As a result, the daily erosion rates by $S$. viride on the deeper reef are lower than on the shallow reef (ca 14\% lower for initial phase fish, and ca 19\% lower for terminal phase fish).

\section{Mass and source of sediment ingested}

Dry mass of empty guts increased linearly with BM, and was not significantly different for Scarus vetula and Sparisoma viride $\left(\right.$ ANCOVA, $F_{(1,19)}=1.734, \mathrm{p}=$ 0.205). Dry mass of empty guts averaged $0.7 \%$ of BM. Also the mass of the ash fraction of empty guts was not significantly different between the species (ANCOVA, $F_{(1.18)}=0.239, \mathrm{p}=0.631$ ), and was ca $0.1 \%$ of BM.

Mass of sediment ingested per bite by Scarus vetula is plotted against body mass in Fig. 6. In spite of the fact that this species feeds primarily by scraping epilithic algal turfs from the surface of dead coral substrates, carbonate derived from epilithic algae per se constituted only a small proportion of the total sediment ingested by adult fish (compare dotted line with 


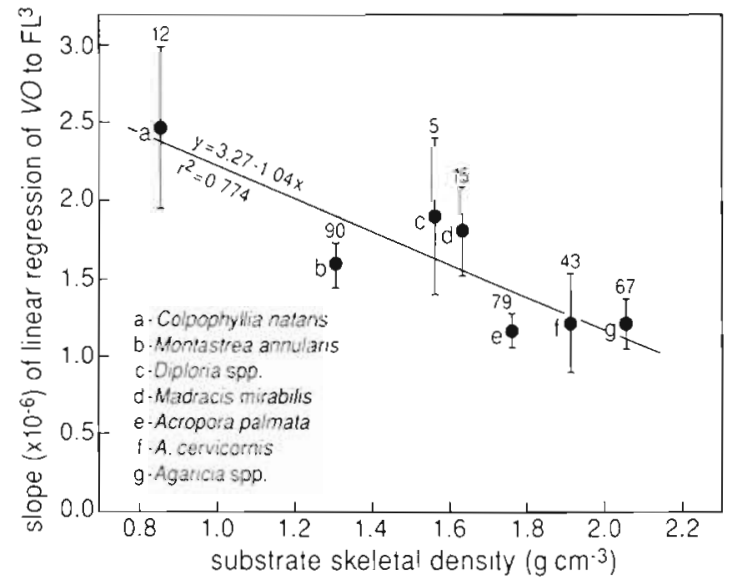

Fig. 2. Sparisoma viride. Effect of substrate skeletal density on the volume (VO) of grazing scars. Regression coefficients $\left( \pm \mathrm{SE}\right.$ ) of least squares regressions of grazing scar $\mathrm{VO}$ to $\mathrm{FL}^{3}$ for each type of dead coral substrate are plotted against their skeletal density. Numbers indicate the number of grazing scars measured. Solid line indicates the least-squares regression through the means

solid line). As indicated by the regression equation, carbonate derived from epilithic algae is probably the main source of sediment ingested by fish smaller than ca $70 \mathrm{~g} \mathrm{BM}( \pm 17 \mathrm{~cm} \mathrm{FL})$.

Sparisoma viride ingested $>5$ times as much sediment per bite than Scarus vetula (Fig. 6), reflecting their excavating feeding mode. Although $S$. viride ingested higher amounts of carbonate derived from epilithic algae than $S$. vetula (due to eating more high biomass algal turfs and to the larger surface area of

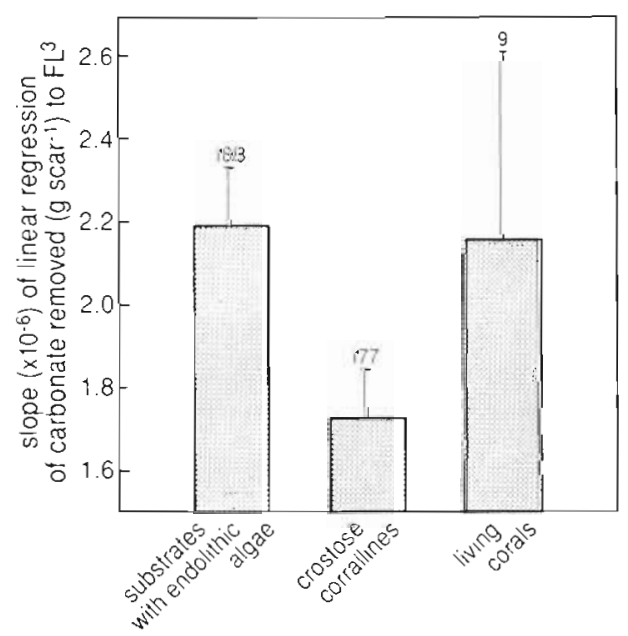

Fig. 3. Sparisoma viride. Effect of food type on mass of carbonate removed from grazing scars. For each food type, the slope \pm SE of least-squares regressions of carbonate mass removed from grazing scars $\left(\mathrm{g} \mathrm{scar}^{-1}\right)$ to $\mathrm{FL}^{3}$ is given. Numbers indicate the number of grazing scars measured

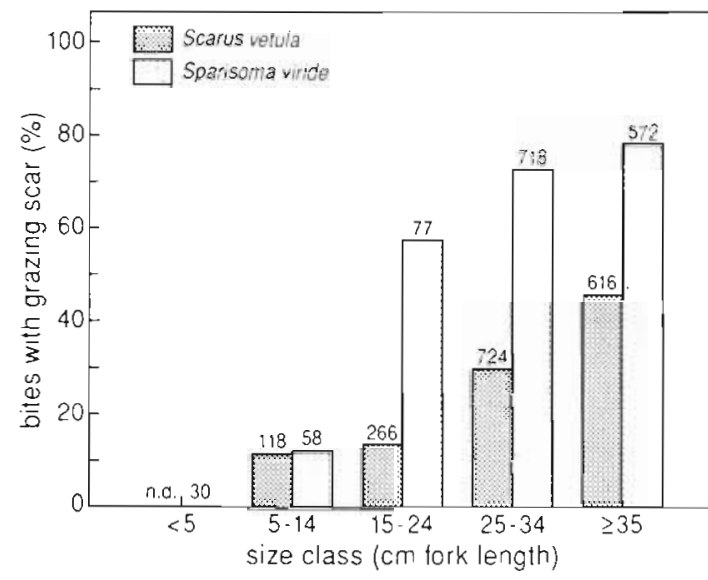

Fig. 4. Scarus vetula and Sparisoma viride. Proportion of bites that leave a visible grazing scar as a function of fish size. Numbers indicate total number of bites observed; n.d.: no data

bites), this sediment source constituted a smaller proportion of total ingested sediment than in $S$. vetula. The regression equation indicates that sediment from sources other than carbonate derived from epilithic algae per se was ingested by fish weighing ca $45 \mathrm{~g}$ ( $\pm 14 \mathrm{~cm} \mathrm{FL}$ ) or more.

For all size classes of Scarus vetula and Sparisoma viride, the mean sediment mass ingested per bite

Table 2. Scarus vetula and Sparısoma viride. Mean daily feeding rates (no. bites $\mathrm{d}^{-1}$ ) \pm SE for different size classes, life phases and social categories. Data for $S$. vetula from Bruggemann et al. (1994c), data for S. viride from Bruggemann et al.

(1994b)

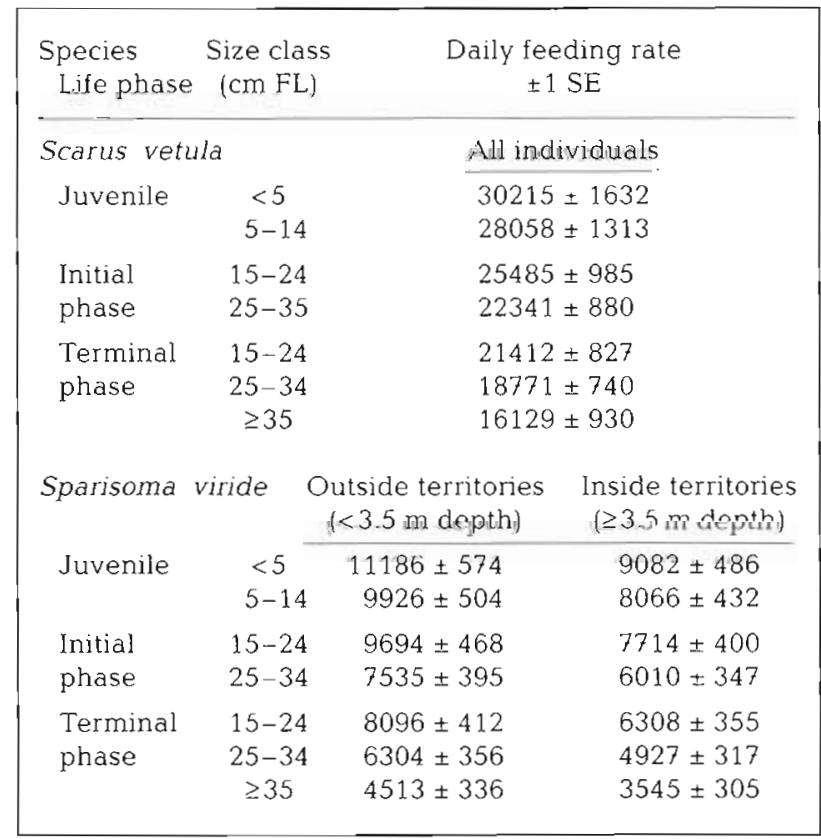




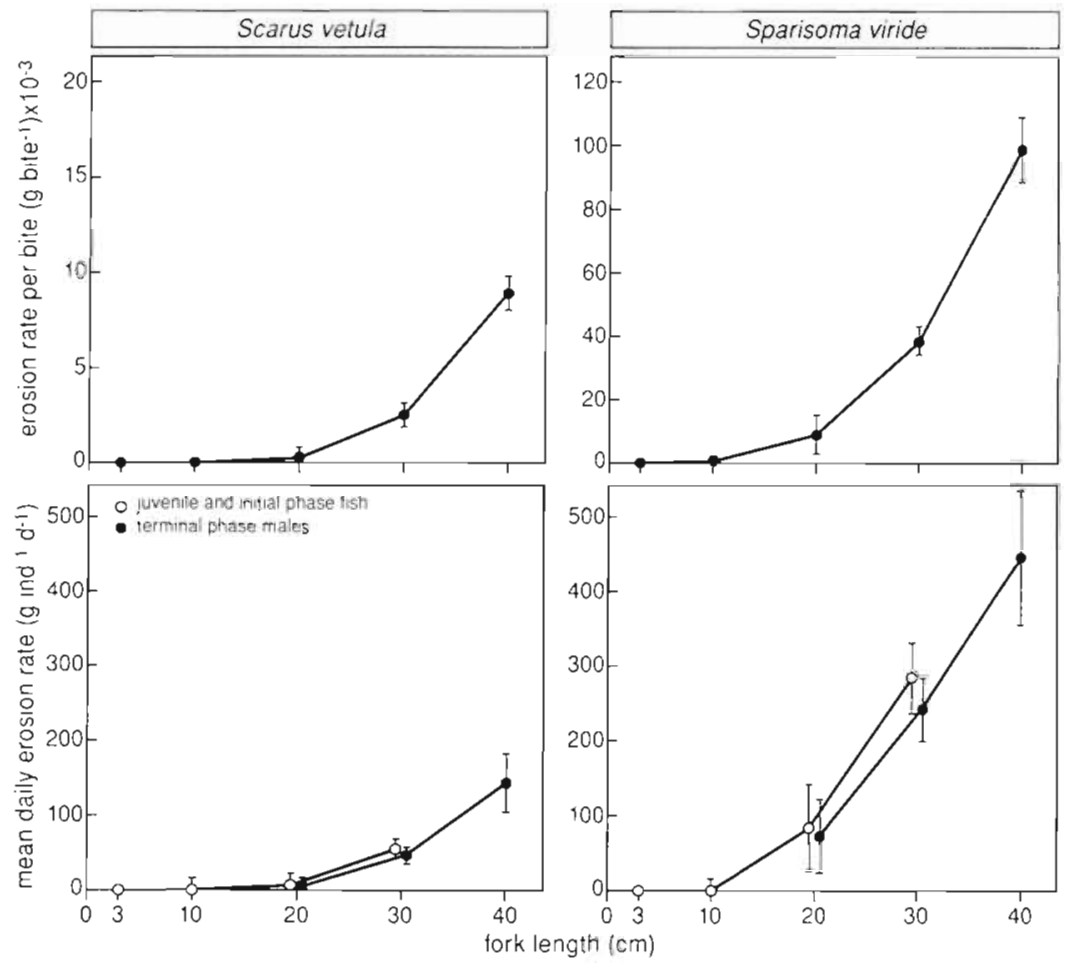

Fig. 5. Scarus vetula and Sparisoma viride. Erosion rates per bite (upper graphs) and per day (lower graphs) as a function of fish size. Error bars indicate $95 \% \mathrm{CI}$.

Note the difference in scale of the $y$-axis between 2 upper graphs

\section{Relative importance of Scarus vetula and Sparisoma viride as bioeroders}

The relative importance of both scarid species as bioeroders in different reef zones is shown in. Table 3. In spite of lower erosion rates by individual Scarus vetula, this species contributes $19-36 \%$ to the total erosion by scarids on the reef, the amount varying with reef zone. This is due to the high abundance and relatively large size of the species. However, Sparisoma viride was the main bioeroder in all reef zones at the study site.

\section{Fish habitat use and spatial patterns of bioerosion}

The distribution of parrotfish on the reef defines the larger spatial pattern of grazing erosion, while the food preference of fish determines erosional rates on the level of individual substrates used for grazing.

Erosion rates were highest on the shallow reef zone, and decreased with depth, resulting from decreasing

exceeded the mean erosion rate per bite. This indicates that our direct estimates of the erosion rate per bite (as calculated from grazing scar size and frequency, and substrate density) are not too high.

The sources of ingested sediment change with fish size (Fig. 7). Carbonate derived from epilithic algae per se accounted for most of the sediment ingested by juvenile fish, whereas a considerable proportion of the sediment ingested by adult fish was derived from grazed substrates, the amount increasing with fish size. For larger juveniles (5 to $14 \mathrm{~cm}$ FL), the ingested sediment could not be allocated with confidence to a particular sediment source (see Fig. 6: for small fish the 95\% confidence limits are large with respect to the actual amount of sediment ingested). Although the ingested sediment might have been derived partially from grazed substrates, as implied by the occurrence of some grazing scars (see Fig. 4), the proportion of substrate derived sediment must be very low considering the feeding habits of juvenile fish. Alternatively, carbonate derived from epilithic algae might fully account for the total sediment ingested by larger juveniles. Adult Sparisoma viride derived a much greater proportion of the ingested sediment from substrates than did $S$. vetula (Fig. 7), reflecting the difference between their excavating and scraping feeding modes, respectively. densities of adult fish (Table 3, Fig. 8B). In all reef zones, food type-specific erosion rates were highest for dead coral substrates inhabited by endolithic algae (Fig. 8B), ranging from $12.2 \mathrm{~kg} \mathrm{~m}^{-2} \mathrm{yr}^{-1}$ on the shallow reef to $1.9 \mathrm{~kg} \mathrm{~m}^{-2} \mathrm{yr}^{-1}$ on the reef slope. Substrates covered with crustose coralline algae were subject to intermediate rates of erosion, ranging from 4.1 to $0.2 \mathrm{~kg} \mathrm{~m}^{-2} \mathrm{yr}^{-1}$, and decreasing with depth. Differences in food type-specific erosion rates are caused by the preference of both parrotfish species for grazing on substrates inhabited by endolithic algae which have a relatively low abundance on the reef (Fig. 8A), and by Sparisoma viride removing a higher mass of carbonate with each bite from these substrates than from sub-

Table 3. Scarus vetula and Sparisoma viride. Erosion rates $\left(\mathrm{kg} \mathrm{m}^{2} \mathrm{yr}^{-1}\right) \pm \mathrm{SE}$ by their populations on the fringing reef of Karpata

\begin{tabular}{|lcccc|}
\hline Species & $\begin{array}{c}\text { Shallow } \\
\text { reef }\end{array}$ & $\begin{array}{c}\text { Gorgonian } \\
\text { zone }\end{array}$ & $\begin{array}{c}\text { Drop- } \\
\text { off }\end{array}$ & $\begin{array}{c}\text { Reef } \\
\text { slope }\end{array}$ \\
\hline S. vetula & $2.42 \pm 0.19$ & $0.87 \pm 0.13$ & $0.38 \pm 0.06$ & $0.14 \pm 0.03$ \\
S. viride & $5.38 \pm 0.43$ & $1.53 \pm 0.18$ & $1.05 \pm 0.14$ & $0.55 \pm 0.09$ \\
Total & $7.62 \pm 0.47$ & $2.40 \pm 0.22$ & $1.43 \pm 0.15$ & $0.69 \pm 0.10$ \\
\hline
\end{tabular}




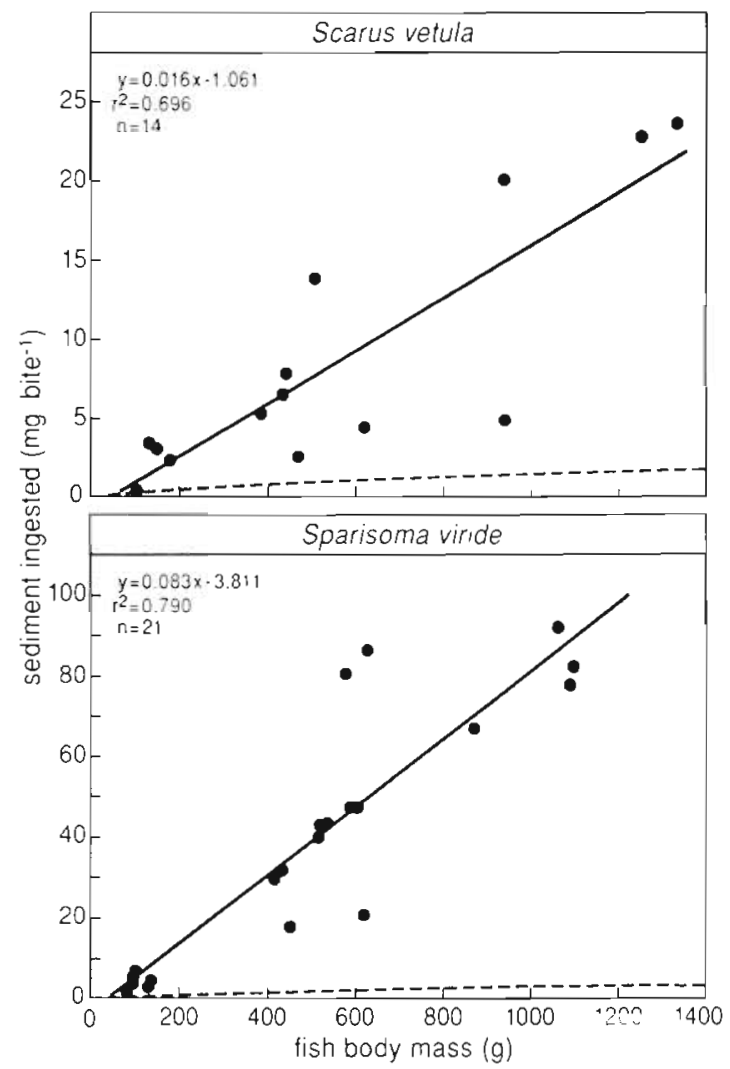

Fig. 6. Scarus vetula and Sparisoma vinde Sedıment ingested per bite in relation to fish body mass. Solid lines indicate total mass of sediment ingested regressed against fish body mass. while grey areas indicate $95 \% \mathrm{Cl}$ for these regressions Dotted lines indicate ingested mass of carbonate dernved from epilithic algae (excluding all other sources) Equations in upper left-hand corner represent mass of total ingested sed1ment minus mass of carbonate from epllithic algae regressed against fish body mass. Note the difference in scale of the $y$-axis between the graphs

strates covered by crustose corallines As hving corals were not eaten by Scarus vetula, and constituted only a minor proportion of the diet of $S$ virde, they experienced the lowest rates of carbonate removal 0.4 to $0.1 \mathrm{~kg} \mathrm{~m}^{-2} \mathrm{yr}^{-1}$ (Fig. 8B).

\section{DISCUSSION AND CONCLUSIONS}

The results of this study on Scarus vetula and Sparisoma viride provide the first systematic assessment of the effects of fish size and feeding mode on erosion rates and sources of sediment ingested by parrotfish. Furthermore, direct observations of their grazing activities and distribution on the reef enable an evaluation of the variability of erosion rates at 2 spatial scales: reef zones and substrate types used for grazing

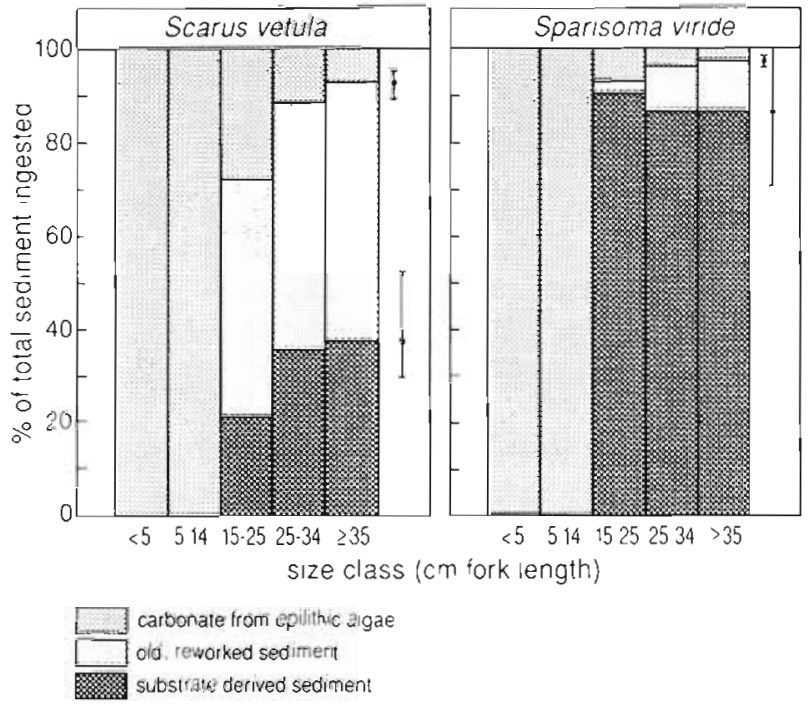

Fig 7 Scarus vetula and Spansoma vinde Partitioning of sediment ingested per bite determined from grazıng scars. Erior bars indicate the widest possible range of values obtanned using the $95 \% \mathrm{Cl}$ of total sediment intake per bite (Fig 6)

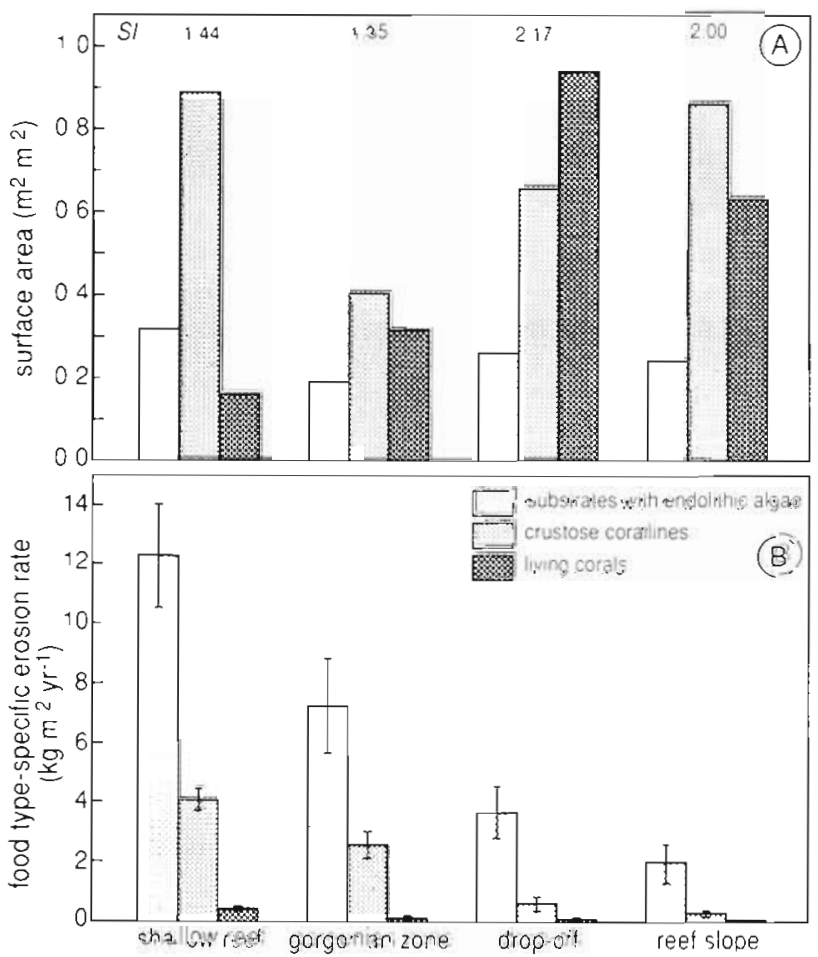

Fig 8 (A) Surface index (SI) in different reef zones and surface area of substrates with endolithic algae, crustose corallines and living corals (B) Food type-specific erosion caused by Scarus vetula and Sparisoma vinde Error bars indicate $\pm 95 \% \mathrm{CI}$ 


\section{Scarus vetula and Sparisoma viride: both significant bioeroding scarids}

We have demonstrated that not only excavating grazers such as Sparisoma viride are important bioeroders, but that also large scrapers such as Scarus vetula can cause significant bioerosion. These 2 scarid species are probably the main contributors to overall erosion rates on Bonaire's fringing reef, due to their high abundance and their large body size in comparison to other grazers. Other scrapers, such as Scarus taeniopteris and $S$. iserti, are abundant (sensu Bellwood \& Choat 1990, Bruggemann et al. 1994c) but have much smaller body size than $S$, vetula (Table 2). Also the small Sparisoma aurofrenatum should be classified as a functional scraper. The larger Sparisoma chrysopterum and $S$. rubripinne are probably excavators (F. Vaandrager unpubl. results), but these species constitute only $1.5 \%$ of the total scarid biomass. Acanthurids and pomacentrids do not harvest substratebound algae (crustose corallines and endolithic algae) in significant amounts. Instead they feed on diatoms and epilithic algae, and ingest mainly old sediment trapped in algal turfs (Randall 1967). Other excavating grazers, such as sea urchins, presently have low densities (Bruggemann et al. 1995), leaving $S$. vetula and $S$. viride as the main contributors to grazing erosion.

\section{Sediment production and ingestion: effects of ontogeny and feeding mode}

Ontogenetic changes in food selection and food intake have been demonstrated in Scarus vetula (Bruggemann et al. 1994c) and in Sparisoma viride (Bruggemann et al. 1994a, b). Juvenile parrotfish feed mainly on epilithic algal turfs, while larger fish derive an increasing proportion of their food from substratebound algal fractions. This change in food composition is reflected in the proportion of bites that leave grazing scars (Fig 4) and in the rates of erosion (Fig. 5), both increasing strongly with fish size. Comparison of the sediment mass removed from scars with the sediment mass ingested per bite showed that juvenile scarids probably derived all ingested carbonate from epilithic algae, while in larger fish an increasing proportion of the total ingested sediment was derived from hard substrates (Fig. 7).

The difference in feeding mode between the scraper Scarus vetula and the excavator Sparisoma viride is also reflected in grazing scar frequency (Fig. 4), erosion rate (Fig. 5) and in the composition of the ingested sediment (Fig. 7). These results confirm the notion based on previous results from laboratory experiments that $S$. vetula derives a smaller proportion of its food from substrate-bound algal fractions than does $S$. viride (Bruggemann et al. 1994b, c). Differences in feeding mode are exhibited in the morphology of the mouth parts. In $S$. vetula, the premaxilla and dentary are set with broad-edged teeth that are worn to an even cutting edge, optimizing the surface area of epilithic algae that can be scraped off in one bite. In the excavator $S$. viride, dental plates are set with alternately protruding teeth on the vertical tooth row, resulting in a crenate cutting edge which may be particularly efficient for cracking the brittle structure of coralline substrata (Bellwood \& Choat 1990).

\section{Comparisons of scarid erosion rates: methodology, time, and space}

The erosion rates by scarid populations reported here (Table 3) are higher than previous estimates for scarids in the Caribbean (Gygi 1975. Ogden 1977, Frydl \& Stearn 1978, Scoffin et al. 1980), and fall in the range of erosion rates reported for the sea urchin Diadema antillarum before their mass-mortality in 1983 (Ogden 1977, Scoffin et al. 1980). Higher scarid erosion rates can be partly attributed to higher rates for individual fish. For instance, erosion rates by terminal phase Sparisoma viride as determined by Gygi (1975) are an order of magnitude lower than our own values. The indirect method employed by this author involved an estimation of gut turnover rate which was too low: 'once a day', while gut turnover rate is in the order of $10 \mathrm{~d}^{-1}$ for S. viride (J.H.B. unpubl, results). However, the high scarid erosion rates at our study site are primarily due to higher densities of the main bioeroding scarids compared to other Caribbean sites (Alevizon \& Landmeier 1984, Lewis \& Wainwright 1985). Only at St. Croix were the scarid densities as reported by Carpenter (1990) similar to those found at Karpata, but these consisted mainly of juvenile fish. The high density of adult scarids is probably due to the fact that fishing disturbance is minimal on Bonaire, and may further be the outcome of the recent ecological history of this fringing reef. White band disease killed off most Acropora cervicornis and $A$. palmata colonies during 1980 to 1982 (Bak \& Criens 1981, van Duyl 1985), and tropical storms that hit the island in 1986 and 1988 broke off most dead coral colonies still standing in situ. These events have increased the surface area suitable for growth of benthic algae, from which herbivore populations must have benefited. Moreover, the mass mortality of Diadema antillarum (Bak et al. 1984) removed an important food competitor of herbivorous fish (Hay \& Taylor 1985. Carpenter 1990, Robertson 1991). Largescale recovery of sea urchin populations has not occurred on the reefs of Bonaire, and parrotfish are 
now the main consumers of the algal production (Bruggemann et al. 1995)

Recent work by Bellwood (1995a) enabled a comparison of scarid erosion rates between Caribbean and Indo-Pacific reefs. Based on the available data, he suggested that a significant difference in the relative importance of scarids as bioeroders may exist between the 2 regions. However, our estimates of erosion rates by scarid populations at Karpata are close to the values reported by Kiene (1988) and Bellwood (1995a) for the Great Barrier Reef. These results argue against such a geographic difference in bioeroding potential of scarid populations, and indicate that local conditions and/or the recent ecological history of a reef, affecting scarid abundance, may be more important determinants of scarid erosion rates.

On the other hand, differences in excavating power by individual scarid taxa may reflect a difference in evolutionary history between Indo-Pacific and Atlantic coral reefs. Erosion rates by 2 excavating scarids from the Great Barrier Reef were quantified by Bellwood (1995a) using the same methods as used in the present study. Daily erosion rates for the smaller Chlorurus sordidus ( 15 to $20 \mathrm{~cm}$ standard length) were close to our values for similar sized Sparisoma viride (mean $\pm 95 \%$ CI: $65 \pm 9$ and $80 \pm 53 \mathrm{~g}$ ind $\mathrm{d}^{-1} \mathrm{~d}^{-1}$, respectively). How ever, daily erosion rates for the larger Chlorurus gibbus (35 to $44 \mathrm{~cm}$ standard length) are much higher than those determined here for Sparisoma viride (corrected for differences in size, mean $\pm 95 \%$ CI: $2788 \pm$ 510 and $550 \pm 50 \mathrm{~g}$ ind. ${ }^{-1} \mathrm{~d}^{-1}$, respectively). Compared to the Caribbean, Indo-Pacific scarids may have evolved in closer association with coral reef environments, resulting in a wider radiation and specialization of scarid taxa into excavating and scraping forms on Indo-Pacific reefs (Bellwood 1994, 1995a).

\section{Spatial variability of bioerosion rates}

On the scale of reef zones, the bioerosion rates at Karpata were determined by the spatial distribution of adult Scarus vetula and Sparisoma viride. Bioerosion rates were highest in the upper reef zones, and decreased with depth. The shallowest part of the reef, the reef crest ( 0 to $0.3 \mathrm{~m}$ depth), was largely protected from erosion by grazing, due to its inaccessibility to grazing fish under normal weather conditions (J.H.B. pers obs.). This was manifest also in the very high biomass of macroalgae on the reef crest. Highest rates of erosion by grazing at intermediate depths, and low rates on shallow reef flats and at $>20 \mathrm{~m}$ depth, were found also by Kiene (1988) and Kiene \& Hutchings (1994a), using experimental substrates. The general pattern of erosion rates decreasing with depth reflects the preference of the main bioeroding grazers, i.e. sea urchins and scarids, for shallow feeding sites (Bak 1976, Hay 1981, Russ 1984a, b, Lewis \& Wainwright 1985, Bellwood 1995b).

The feeding habits of parrotfish determine the rate of destruction of reef surfaces on a small spatial scale. Both the foraging preferences of these fish, and the effects of food type (Bruggemann et al. 1994a; Fig. 3) and substrate density (Fig. 3) on the size of the grazing scars attained by the excavator Sparisoma viride, result in large differences in excavation rates on the level of individual food patches or (dead) coral substrate types. In this way, the interaction between boring algae and grazing fish can result in very rapid destruction of reef surface (>12 $\mathrm{kg} \mathrm{m}^{-2} \mathrm{yr}^{-1}$; Fig. 8). Being large and mobile, parrotfish can actively select preferred food sources. Therefore, the effect of parrotfish grazing may differ from that of sea urchins that have smaller feeding ranges. Their mobility and their aptness in harvesting substrate-bound algal fractions make parrotfish probably the most efficient reef excavators in modern reefs (Vogel 1993).

Internal bioeroders have limited chance to settle and survive under high grazing pressure, such as found on the shallow reef and on substrates inhabited by endolithic algae. Borer communities that modify the carbonate framework internally may contribute more to the erosion of dead coral substrates when they are maintained in situ for longer periods of time (Hutchings 1986, Kiene 1988). Reef surfaces that are covered with crustose coralline algae derive some protection against destruction by grazing fish, especially on the deeper reef zones where grazing rates are lower, and borer communities can be expected to contribute significantly to the bioerosion of these substrates.

\section{Methodology and sources of variance}

In the present study, the erosional impact of parrotfish grazing on reef substrates was assessed using direct methods to quantify carbonate removal from grazing scars in combination with field observations of fish foraging behaviour and the spatial distribution of size classes. By describing the effects of fish size and feeding mode on erosion rates, a more detailed appraisal of scarid erosion than hitherto possible has been achieved.

Indirect estimates of scarid erosion often involve measurement of sediment throughput and correcting for reworked sediment. These variables are difficult to quantify, and vary according to species, size and life phase of fish. By using direct methods, these problems are avoided. Moreover, direct field observations of foraging behaviour of major bioeroding species can pro- 
vide explanations for the sources of variance in erosion rates found in studies using experimental substrates (Kiene 1988, Kiene \& Hutchings 1994a, b).

Error terms for the estimates of parrotfish erosion rates presented in this study were obtained by taking all major sources of variance into account: parrotfish abundance, size of grazing scars and daily feeding rates. Moreover, the effects of fish size and feeding mode on grazing scar frequency, and the effects of food type and substrate density were incorporated in the calculations of erosion rates. Seasonal effects on erosion rates were not calculated. Daylength variation caused Sparisoma viride to take $12 \%$ more bites daily in summer than in winter (Bruggemann et al. 1994b), and this will affect daily erosion rates proportionally. An effect of daylength on daily feeding rates of Scarus vetula was not detected (Bruggemann et al. 1994c).

Acknowledgements. The authors thank the Bonaire Marine Park authorities for the research permission and working facilities at Karpata Ecological Centre. This work was funded by the Netherlands Foundation for the Advancement of Tropical Research (WOTRO). A.M.v.K. received financial support from the Royal Dutch Academy of Sciences. We are indebted to Dr W. E. Kiene and Prof. Dr K. Vogel for their ideas and facilities offered to analyze the density of dead coral substrates inhabited by endoliths. Mrs N. Pohlmann made preparations of substrates for SEM photographs which were taken by Mr J Tochtenhagen. André van de Beek helped with the image analysis, while Dr A. Boomsma provided valuable advice on statistical analysis. Dick Visser prepared the figures. We thank Prof. Dr C. van den Hoek, Dr W. E. Kiene and several anonymous reviewers for critical advice on an earlier version of the manuscript.

\section{LITERATURE CITED}

Alevizon W, Landmeier D (1984) Variability in the population structures of four western Atlantic parrotfishes. Environ Biol Fish 10:149-158

Bak RPM (1976) The growth of coral colonies and the importance of crustose coralline algae and burrowing sponges in relation with carbonate accumulation. Neth J Sea Res 10:285-337

Bak RPM (1990) Patterns of echinoid bioerosion in two Pacific coral reef lagoons. Mar Ecol Prog Ser 66:267-272

Bak RPM (1994) Sea urchin bioerosion in coral reefs: place in the carbonate budget and relevant variables. Coral Reefs 13:99-103

Bak RPM, Carpay MJE, de Ruyter van Steveninck ED (1984) Densities of the sea urchin Diadema antillarum before and after mass mortalities on the coral reefs of Curaçao. Mar Ecol Prog Ser 17:105-108

Bak RPM, Criens SR (1981) Survival after fragmentation of colonies of Madracis mirabilis, Acropora palmata and $A$ cervicornis (Scleractinia) and the subsequent impact of a coral disease. Proc 4th Int Symp Coral Reefs 2:221-227

Bellwood DR (1994) A phylogenetic study of the parrotfishes family Scaridae (P1sces: Labroidel), with a revision of genera. Rec Aust Mus, Suppl 20

Bellwood DR (1995a) Direct estimate of bioerosion by two parrotfish species, Chlorurus gibbus and C. sordidus, on the Great Barrier Reef, Australia. Mar Biol 121:419-429

Bellwood DR (1995b) Carbonate transport and within-reef patterns of bioerosion and sediment release by parrotfishes (family Scaridae) on the Great Barrier Reef. Mar Ecol Prog Ser 117:127-136

Bellwood DR, Choat JH (1990) A functional analysis of grazing in parrotfishes (family Scaridae): the ecological implications. Environ Biol Fish 28:189-214

Bruggemann JH, Begeman J, Bosma EM, Verburg P, Breeman AM (1994b) Foraging by the stoplight parrotfish Sparisoma viride. II. Intake and assimilation of food, protein and energy. Mar Ecol Prog Ser 106:57-71

Bruggemann JH, Kuyper MWM, Breeman AM (1994c) Comparative analysis of foraging and habitat use by the sympatric Caribbean parrotfish Scarus vetula and Sparisoma viride (Scaridae). Mar Ecol Prog Ser 112:51-66

Bruggemann JH, van Oppen MJH, Breeman AM (1994a) Foraging by the stoplight parrotfish Sparisoma viride. I. Food selection in different, socially determined habitats. Mar Ecol Prog Ser 106:41-55

Bruggemann $J H$, van Rooij JM, Videler JJ, Breeman AM (1995) Dynamics and limitations of herbivore populations on a Caribbean coral reef. In: Bruggemann JH. Parrotfish grazing on coral reefs: a trophic novelty. PhD thesis, University of Groningen

Carpenter RC (1990) Mass mortality of Diadema antillarum. II. Effects on population densities and grazing intensity of parrotfishes and surgeonfishes. Mar Biol 104:79-86

Davies PJ (1983) Reef growth. In: Barnes DJ (ed) Perspectives on coral reefs. Brian Clouston, Canberra, p 69-106

Davies PJ, Hutchings PA (1983) Initial colonization, erosion and accretion on coral substrate: experimental results Lizard Island Great Barrier Reef. Coral Reefs 2:27-35

Frydl P, Stearn CW (1978) Rate of bioerosion by parrotfish in Barbados reef environments. J Sedim Petrol 48:1149-1158

Gygi RA (1975) Sparisoma viride (Bonnaterre), the stoplight parrotfish, a major sediment producer on coral reefs of Bermuda. Eclog Geol Helv 68:327-359

Hay ME (1981) Spatial patterns of grazing intensity on a Caribbean barrier reef: herbivory and algal distribution. Aquat Bot 11:97-109

Hay ME, Taylor PR (1985) Competition between herbivorous fishes and sea urchins on Caribbean reefs. Oecologia 65: $591-598$

Horn MH (1989) Biology of marine herbivorous fishes. Oceanogr Mar Biol A Rev 27:167-272

Hubbard DK, Miller AI, Scaturo D (1990) Production and cycling of calcium carbonate in a shelf-edge reef system (St. Croix, US Virgin Islands): applications to the nature of reef systems in the fossil record. I Sedim Petrol 60: $335-360$

Hubbard DK, Scaturo D (1985) Growth rates of seven species of scleractincan corals from Cane Bay and Salt River, St. Croix. Bull Mar Sci 36:325-338

Hudson JH (1977) Long-term bioerosion rates on a Florida reef: a new method. Proc 3rd Int Symp Coral Reefs 2: 491-497

Hutchings PA (1986) Biological destruction of coral reefs. Coral Reefs $4: 239-252$

Kiene WE (1985) Biological destruction of experimental coral substrates at Lizard Island (Great Barrier Reef, Australia). Proc 5th Int Symp Coral Reefs 5:339-344

Kiene WE (1988) A model of bioerosion on the Great Barrier Reef. Proc 6th Int Symp Coral Reefs 3:449-454

Kiene WE Hutchings PA (1994a) Bioerosion experiments at Lizard Island, Great Barrier Reef. Coral Reefs 13:91-98 
Kiene WE, Hutchings PA. (1994b) Long-term bioerosion of experimental coral. substrates from Lizard Island, Great Barrier Reef. Proc 7th Int Symp Coral Reefs 1:397-403

Lewis SM (1986) The role of herbivorous fishes in the organization of a Caribbean reef community. Ecol Monogr 56: $183-200$

Lewis SM, Waınwright PC (1985) Herbivore abundance and grazing intensity on a Caribbean coral reef. J Exp Mar Biol Ecol 87:215-228

Norusis MJ (1990) SPSS/PC+ 4.0 for the IBM PC/XT/AT and PS/2. Vol I, Base manual; Vol II, Statistics; Vol III, Advanced statistics. SPSS Inc, Chicago

Ogden JC (1977) Carbonate-sediment production by parrot fish and sea urchins on Caribbean reefs. In: Frost $\mathrm{SH}$, Weiss MP, Saunders JB (eds) Reefs and related carbon. ates. Ecol Sediment Am Ass Petrol Geol, Studies in Geology $4: 281-288$

Porter JW (1972) Patterns of species diversity in Caribbean reef corals. Ecology 53:745-748

Randall JE (1967) Food habits of reef fishes of the West Indies. Stud Trop Oceanogr 5:665-847

Robertson DR (1991) Increases in surgeonfish populations after mass mortality of the sea urchin Diadema antillarum in Panama indicate food limitation. Mar Biol 111:437-444

This article was submitted to the editor
Russ G (1984a) Distribution and abundance of herbivorous grazing fishes in the central Great Barner Reef. I. Levels of variability across the entire continental shelf. Mar Ecol Prog Ser 20:23-34

Russ G (1984b) Distribution and abundance of herbivorous grazing fishes in the central Great Barrier Reef. II. Patterns of zonation of mid-shelf and outershelf reefs. Mar Ecol Prog Ser 20:35-44

Scoffin TP, Stearn CW, Boucher D. Frydl P, Hawkins CM, Hunter 1G, MacGeachy JK (1980) Calcuum carbonate budget of a fringing reef on the west coast of Barbados. Part II. Erosion, sediments and internal structure. Bull Mar Sci 30: $475-508$

Stearn CW, Scoffin TP, Martindale W (1977) Calclum carbonate budget of a fringing reef on the west coast of Barbados. Part 1. Zonation and productivity. Bull Mar Scr 27 : $479-510$

Travis J (1982) A method for the statistical analysis of timeenergy budgets. Ecology 63:19-25

van Duyl FC (1985) Atlas of the living reefs of Curaçao and Bonaire (Netherlands Antilles), Vol 117 Foundation for Scientific Research in Surinam and the Netherlands Antilles, Utrecht

Vogel K (1993) Bioeroders in fossil reefs. Facies 28:109-114

Manuscript first received: October 28, 1994

Revised version accepted: October 20, 1995 